\title{
Surfactant-Assisted Growth of CdS Thin Films for Photovoltaic Applications
}

Conference Paper NREL/CP-520-38941

November 2005

C.L. Perkins and F.S. Hasoon

Presented at the 2005 DOE Solar Energy Technologies Program Review Meeting November 7-10, 2005

Denver, Colorado 


\section{NOTICE}

The submitted manuscript has been offered by an employee of the Midwest Research Institute (MRI), a contractor of the US Government under Contract No. DE-AC36-99G010337. Accordingly, the US Government and MRI retain a nonexclusive royalty-free license to publish or reproduce the published form of this contribution, or allow others to do so, for US Government purposes.

This report was prepared as an account of work sponsored by an agency of the United States government. Neither the United States government nor any agency thereof, nor any of their employees, makes any warranty, express or implied, or assumes any legal liability or responsibility for the accuracy, completeness, or usefulness of any information, apparatus, product, or process disclosed, or represents that its use would not infringe privately owned rights. Reference herein to any specific commercial product, process, or service by trade name, trademark, manufacturer, or otherwise does not necessarily constitute or imply its endorsement, recommendation, or favoring by the United States government or any agency thereof. The views and opinions of authors expressed herein do not necessarily state or reflect those of the United States government or any agency thereof.

Available electronically at http://www.osti.gov/bridge

Available for a processing fee to U.S. Department of Energy and its contractors, in paper, from:

U.S. Department of Energy

Office of Scientific and Technical Information

P.O. Box 62

Oak Ridge, TN 37831-0062

phone: 865.576.8401

fax: 865.576 .5728

email: mailto:reports@adonis.osti.gov

Available for sale to the public, in paper, from:

U.S. Department of Commerce

National Technical Information Service

5285 Port Royal Road

Springfield, VA 22161

phone: 800.553 .6847

fax: 703.605.6900

email: orders@ntis.fedworld.gov

online ordering: http://www.ntis.gov/ordering.htm 


\title{
Surfactant-Assisted Growth of CdS Thin Films for Photovoltaic Applications
}

\author{
Craig L. Perkins and Falah S. Hasoon \\ National Renewable Energy Laboratory, Golden, CO, craig_perkins@nrel.gov
}

\begin{abstract}
A common non-ionic surfactant, Triton $X-100$, was used to modify the chemical bath deposition (CBD) of CdS "buffer" layers on $\mathrm{Cu}(\mathrm{In}, \mathrm{Ga}) \mathrm{Se}_{2}$ (CIGS) thin films. X-ray photoelectron spectroscopy (XPS) and Auger electron spectroscopy (AES) data demonstrate that films produced with the surfactant have about the same levels of impurities as films grown without it. For thin, $\sim 130 \AA$ CdS layers and relative to devices made without the surfactant, average absolute cell efficiencies were increased from $10.5 \%$ to $14.8 \%$, or by a relative $41 \%$. Visual inspection of the CdS depositions reveals one possible mechanism of the surfactant's effects: bubbles that form and adhere to the CIGS surface during the CBD reaction are almost completely eliminated with the addition of the TX-100. Thus, pinholes and thin areas in the CdS layers caused by poor wetting of the substrate surface are sharply reduced, leading to large increases in the open circuit voltage in devices produced with the surfactant.
\end{abstract}

\section{Objectives}

The objective of this work was to capitalize on a serendipitous observation that occurred during the course of another investigation into the surface chemistry occurring on CIGS during CBD of CdS. Observed was the formation of stationary bubbles on CIGS surfaces during CBD of CdS. That combined with the knowledge that the CBD process beneficially changes the composition, work function, and valence band position of as-grown absorbers, resulted in the hypothesis that the addition of a surfactant to the standard CBD might increase the uniformity of thin CdS layers and might therefore increase the performance of solar cells made with such thin CdS layers. Performance increases both in terms of cell efficiencies and reliability that can be brought about by process changes easy to implement in current manufacturing procedures are in line with the goals of the SETP Multi-Year Technical Plan.

\section{Technical Approach}

Central to the technical approach to this work has been the construction and use of a unique cluster tool that consists of interconnected, capital-intensive analysis instrumentation and deposition equipment. The tool, which allows study of surface and interface properties of PV-relevant materials by XPS, AES, mass spectrometry, and in-situ growth represents a contribution to PV research that without Federal support would not be available to the PV community.

In the results reported here and in greater detail elsewhere ${ }^{1,2}$, CIGS films were first grown by the " 3 - stage" process and transported through air into the $\mathrm{N}_{2}$ purged glove box portion of the cluster tool. Thin CdS films were grown on these absorbers by CBD with and without surfactant addition. Thin $(\sim 130 \AA) \mathrm{CdS}$ films were used to purposely enter the regime where device performance begins to suffer as a result of the buffer layer being too thin. The effect of the surfactant addition upon the CdS deposition rate was checked to ensure that comparisons between devices were for devices with buffer layers of similar thicknesses. Chemical and electronic properties of the CdS layers were studied with the surface sensitive spectroscopies ultraviolet photoelectron spectroscopy (UPS), XPS, and AES. The ultra-high vacuum sample transfer portion of the cluster tool allowed the study of asgrown surfaces without exposure to air.

\section{Results and Accomplishments}

The effects of surfactant addition on bubble formation during the CBD of CdS on CIGS were dramatic and easily observed by eye. ${ }^{2}$ These effects are even more pronounced using highly corrugated hydrophobic substrates such as pictured in Fig. 1.
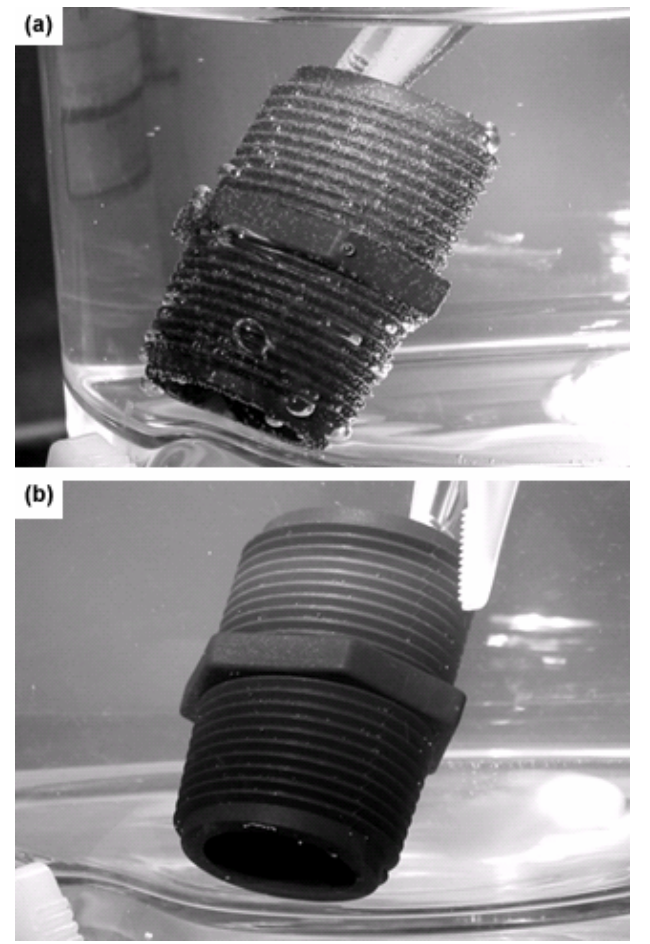

Fig. 1.

CdS CBD on hydrophobic substrates without (a) and with (b) surfactant.

Figure 1 is a photograph $300 \mathrm{~s}$ into a CdS deposition on a black polypropylene nipple commonly used for plumbing. This test substrate was chosen for its 
hydrophobicity, roughness, and visual contrast with lighter-appearing bubbles. As can be observed, surfactant addition to the standard NREL CdS deposition process sharply reduces the formation of adherent bubbles. Uniform and pinhole-free CdS films are deposited on hydrophobic substrates with the surfactant-modified process, whereas the standard CBD process results in films with poor coverage and pinholes that are obvious to the unaided eye (not shown).

AES and XPS data demonstrate that CdS films produced with the surfactant have the same chemical makeup as those produced without. ${ }^{1}$ He I UPS data as in Figure 2 show that the two types of films also have the same work function and valence band position with respect to the Fermi energy.

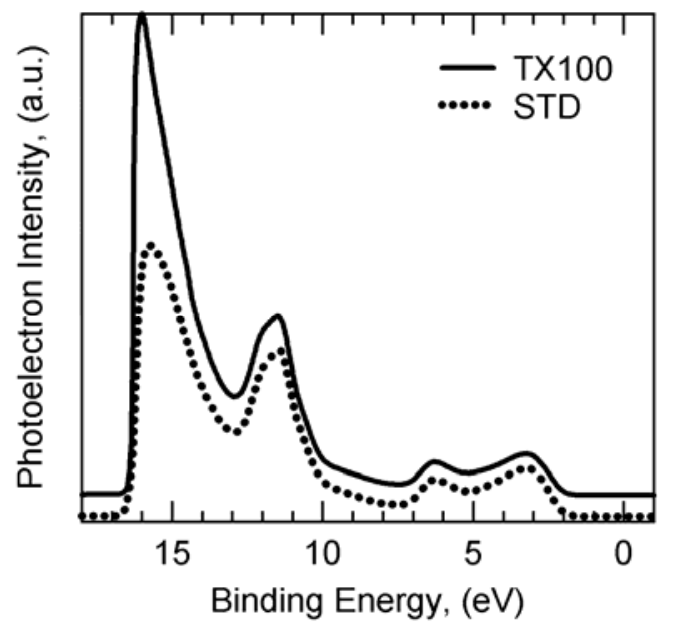

Fig. 2. UPS spectra showing work function and valence band maximum of surfactant (solid line) and standard (dotted line) CBD CdS.

In Figure 2, the work function is given by the difference between the secondary electron cutoff $(\sim$ $16.5 \mathrm{eV})$ and the energy of the incident light (21.218 $\mathrm{eV}$ ). For the standard CdS films this found to be 4.88 $\pm 0.05 \mathrm{eV}$, and for the surfactant-grown films this was $4.87 \pm 0.05 \mathrm{eV}$. The valence band maxima with respect to the Fermi energy ( $0 \mathrm{eV}$ binding energy) of films grown by the standard and surfactant-modified processes were $1.97 \pm 0.05 \mathrm{eV}$ and $1.99 \pm 0.05 \mathrm{eV}$, respectively.

CIGS-based solar cells were produced using $\sim 130 \AA$ of standard and surfactant-grown CdS and sputtered $\mathrm{ZnO}$ window layers, and subsequently tested. Previous device results obtained in this project ${ }^{2}$ were for CdS buffer layers that were even thinner $(\sim 70 \AA)$. Table I shows the results for the $130 \AA$ CdS films on the same CIGS absorber. It is apparent that use of the surfactant results in a large, $\sim 40 \%$ relative increase in the average cell efficiency compared to devices made with the standard CBD process.

Table 1 shows that most of the improvement that results with the surfactant-modified process is in the
Voc as one would expect from a higher quality, pinhole-free, and more uniform buffer layer.

Table 1. Device results for standard (cells 1-6) and surfactant (shaded cells 7-12) CBD processes.

$\begin{array}{ccccc}\text { Cell } & \begin{array}{c}\text { Voc } \\ (\mathbf{V})\end{array} & \begin{array}{c}\mathbf{J s c} \\ \left(\mathbf{m A} / \mathbf{c m}^{-2}\right)\end{array} & \begin{array}{c}\mathbf{F F} \\ \mathbf{( \% )}\end{array} & \begin{array}{c}\mathbf{E f f .} \\ \mathbf{( \% )}\end{array} \\ 1 & 0.481 & -30.63 & 68.35 & 10.07 \\ 2 & 0.482 & -31.28 & 68.43 & 10.31 \\ 3 & 0.488 & -30.57 & 69.32 & 10.33 \\ 4 & 0.487 & -30.86 & 67.10 & 10.08 \\ 5 & 0.495 & -31.51 & 69.77 & 10.89 \\ 6 & 0.529 & -31.00 & 70.47 & 11.55 \\ \text { Avg. } & \mathbf{0 . 4 9 4} & \mathbf{- 3 0 . 9 8} & \mathbf{6 8 . 9 1} & \mathbf{1 0 . 5 4} \\ & & & & \\ 7 & 0.685 & -29.68 & 75.18 & 15.28 \\ 8 & 0.686 & -30.33 & 75.85 & 15.78 \\ 9 & 0.679 & -32.18 & 73.84 & 16.14 \\ 10 & 0.663 & -32.29 & 73.49 & 15.73 \\ 11 & 0.604 & -31.92 & 71.56 & 13.81 \\ 12 & 0.544 & -31.82 & 70.54 & 12.22 \\ \text { Avg. } & \mathbf{0 . 6 4 4} & \mathbf{- 3 1 . 3 7} & \mathbf{7 3 . 4 1} & \mathbf{1 4 . 8 2}\end{array}$

\section{Conclusions}

A common non-ionic surfactant has been shown to substantially improve the performance of CIGS-based solar cells when used in the chemical bath deposition of the n-type CdS buffer layer. XPS, UPS, and AES data demonstrate that the surfactant-modified CBD process produces films with the same chemical and electronic properties as the standard CBD process. Given these facts and that visual inspection of the depositions reveals that the surfactant substantially reduces the formation of adherent bubbles on absorbers, we conclude that performance increases with the surfactant are due to more uniform and pinhole-free buffer layers. Further work will include additional device characterization (LBIC, EL), reliability testing, and testing of suitability of this process for CdTe-based solar cells.

\section{ACKNOWLEDGEMENTS}

The authors would like to thank James Keane and Scott Ward for device finishing, Tom Moriarty for device testing, and Sally Asher and Pete Sheldon for useful discussions. This work was supported by the U.S. Department of Energy under Contract No. DEAC36-99G010337.

\section{REFERENCES}

${ }^{1}$ C. L. Perkins, F.S. Hasoon, to be published.

${ }^{2}$ C. L. Perkins, F.S. Hasoon, H.A. Al-Thani, S.E. Asher, and P. Sheldon, Proceedings of the 31st IEEE Photovoltaics Specialists Conference, Lake Buena Vista, FL (2005). 


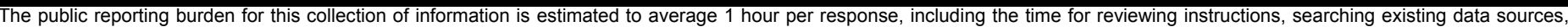

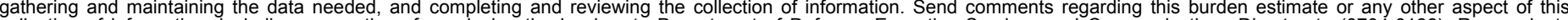

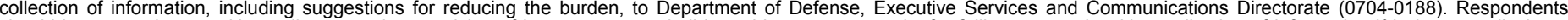

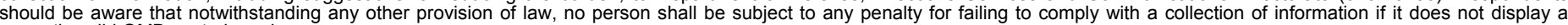
currently valid OMB control number.

PLEASE DO NOT RETURN YOUR FORM TO THE ABOVE ORGANIZATION.

\section{REPORT DATE (DD-MM-YYYY) \\ November 2005 \\ 2. REPORT TYPE Conference Paper}

4. TITLE AND SUBTITLE

Surfactant-Assisted Growth of CdS Thin Films for Photovoltaic Applications
3. DATES COVERED (From - To) 5a. CONTRACT NUMBER

DE-AC36-99-GO10337

5b. GRANT NUMBER

5c. PROGRAM ELEMENT NUMBER

6. AUTHOR(S)

C.L. Perkins and F.S. Hasoon

5d. PROJECT NUMBER

NREL/CP-520-38941

5e. TASK NUMBER

PVA6.3301

5f. WORK UNIT NUMBER

7. PERFORMING ORGANIZATION NAME(S) AND ADDRESS(ES)

National Renewable Energy Laboratory

1617 Cole Blvd.

8. PERFORMING ORGANIZATION

REPORT NUMBER

Golden, CO 80401-3393

NREL/CP-520-38941

9. SPONSORING/MONITORING AGENCY NAME(S) AND ADDRESS(ES)

10. SPONSOR/MONITOR'S ACRONYM(S) NREL

11. SPONSORING/MONITORING AGENCY REPORT NUMBER

12. DISTRIBUTION AVAILABILITY STATEMENT

National Technical Information Service

U.S. Department of Commerce

5285 Port Royal Road

Springfield, VA 22161

\section{SUPPLEMENTARY NOTES}

\section{ABSTRACT (Maximum 200 Words)}

A common non-ionic surfactant, Triton X-100, was used to modify the chemical bath deposition (CBD) of CdS "buffer" layers on $\mathrm{Cu}(\mathrm{In}, \mathrm{Ga}) \mathrm{Se}_{2}$ (CIGS) thin films. X-ray photoelectron spectroscopy (XPS) and Auger electron spectroscopy (AES) data demonstrate that films produced with the surfactant have about the same levels of impurities as films grown without it. For thin, $\sim 130 \AA$ CdS layers and relative to devices made without the surfactant, average absolute cell efficiencies were increased from $10.5 \%$ to $14.8 \%$, or by a relative $41 \%$. Visual inspection of the CdS depositions reveals one possible mechanism of the surfactant's effects: bubbles that form and adhere to the CIGS surface during the CBD reaction are almost completely eliminated with the addition of the TX-100. Thus, pinholes and thin areas in the CdS layers caused by poor wetting of the substrate surface are sharply reduced, leading to large increases in the open circuit voltage in devices produced with the surfactant.

\section{SUBJECT TERMS}

Photovoltaics; solar; CdS thin films; PV; NREL

\begin{tabular}{|c|c|c|}
\hline \multicolumn{3}{|c|}{ 16. SECURITY CLASSIFICATION OF: } \\
\hline $\begin{array}{l}\text { a. REPORT } \\
\text { Unclassified }\end{array}$ & $\begin{array}{l}\text { b. ABSTRACT } \\
\text { Unclassified }\end{array}$ & $\begin{array}{l}\text { c. THIS PAGE } \\
\text { Unclassified }\end{array}$ \\
\hline
\end{tabular}

17. LIMITATION
OF ABSTRACT
UL

18. NUMBER
OF PAGES

19a. NAME OF RESPONSIBLE PERSON

19b. TELEPONE NUMBER (Include area code) 